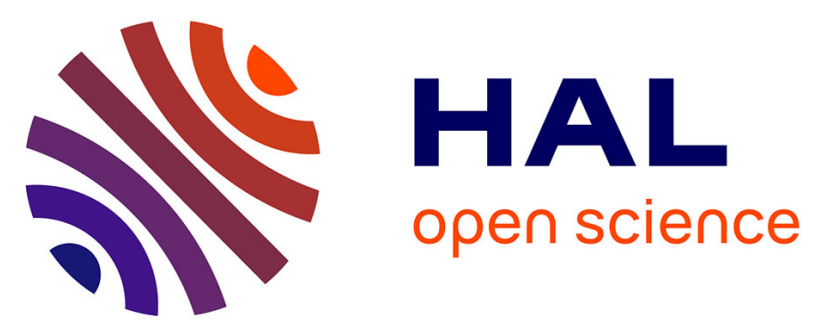

\title{
Anoperineal lesions in Crohn's disease: French recommendations for clinical practice
}

\author{
D. Bouchard, L. Abramowitz, G. Bouguen, C. Brochard, A. Dabadie, V. de
} Parades, M. Eléouet-Kaplan, N. Fathallah, J.-L. Faucheron, L. Maggiori, et al.

\section{- To cite this version:}

D. Bouchard, L. Abramowitz, G. Bouguen, C. Brochard, A. Dabadie, et al.. Anoperineal lesions in Crohn's disease: French recommendations for clinical practice. Techniques in Coloproctology, 2017, 21 (9), pp.683-691. 10.1007/s10151-017-1684-y · hal-01639851

\section{HAL Id: hal-01639851}

\section{https://hal-univ-rennes1.archives-ouvertes.fr/hal-01639851}

Submitted on 1 Dec 2017

HAL is a multi-disciplinary open access archive for the deposit and dissemination of scientific research documents, whether they are published or not. The documents may come from teaching and research institutions in France or abroad, or from public or private research centers.
L'archive ouverte pluridisciplinaire HAL, est destinée au dépôt et à la diffusion de documents scientifiques de niveau recherche, publiés ou non, émanant des établissements d'enseignement et de recherche français ou étrangers, des laboratoires publics ou privés. 


\section{Anoperineal lesions in Crohn's disease: French recommendations for clinical practice}

(RCP)

Concise title: French recommendations for anoperineal Crohn's disease

Authors: Dominique Bouchard ${ }^{\mathrm{a}}$, Laurent Abramowitz ${ }^{\mathrm{b}}$, Guillaume Bouguen ${ }^{\mathrm{c}}$, Charlène Brochard $^{\mathrm{c}}$, Alain Dabadie ${ }^{\mathrm{d}}$, Vincent de Parades ${ }^{\mathrm{e}}$, Marianne Eléouet-Kaplan ${ }^{\mathrm{a}}$, Nadia Fathallah ${ }^{\mathrm{e}}$, Jean-Luc Faucheron ${ }^{\mathrm{f}}$, Léon Maggiori ${ }^{\mathrm{g}}$, Yves Panis $^{\mathrm{g}}$, François Pigot ${ }^{\mathrm{a}}$, Pauline Rouméguère ${ }^{\mathrm{h}}$, Agnès Sénéjoux ${ }^{\mathrm{i}}$, Laurent Siproudhis ${ }^{\mathrm{c}, \mathrm{j}}$, Ghislain Staumont ${ }^{\mathrm{k}}$, Jean-Michel Suduca ${ }^{\mathrm{k}}$, Béatrice Vinson-Bonnet ${ }^{1}$, Jean-David Zeitoun ${ }^{\mathrm{m}}$.

${ }^{\text {a }}$ Service de proctologie, Maison de Santé Protestante Bagatelle, Talence, France

${ }^{\mathrm{b}}$ Proctologie médico-chirurgicale, hôpital Bichat Claude-Bernard, Paris,

France

${ }^{\mathrm{c}}$ Service des maladies de l'appareil digestif, CHU Pontchaillou, Rennes, France

${ }^{\mathrm{d}}$ CHU Pontchaillou, CHU hôpital Sud, Rennes, France

${ }^{\text {e }}$ Service de proctologie médico-chirurgicale, institut Léopold-Bellan, groupe hospitalier Saint-Joseph, Paris, France

${ }^{\mathrm{f}}$ Unité de chirurgie colo-rectale, service de chirurgie digestive et de l'urgence, hôpital Michallon, CHUGA Grenoble, France

${ }^{\mathrm{g}}$ Service de chirurgie colo-rectale, pôle des maladies de l'appareil digestif, hôpital Beaujon, université Paris 7, Clichy, France

${ }^{\mathrm{h}}$ Clinique Tivoli-Ducos, Bordeaux, France

${ }^{\mathrm{i}}$ CHP Saint-Grégoire, Saint-Grégoire, France

${ }^{\mathrm{j}}$ Inserm U991, service de gastro-entérologie, université de Rennes 1, CHU Pontchaillou 
Rennes, France

${ }^{\mathrm{k}}$ Clinique Saint-Jean-Languedoc, Toulouse, France

${ }^{1}$ Service de chirurgie viscérale et digestive, CHI, Poissy-St-Germain-en-Laye, France

${ }^{\mathrm{m}}$ Service de proctologie médico-interventionnelle, centre hospitalier Diaconesses-Croix

Saint-Simon, Paris, France

Correspondence : Dr Dominique Bouchard, Service de Proctologie, Hôpital Bagatelle, 33401

Talence, France.

Phone : 33.5.57.12.35.42. Fax : 33.5.57.12.34.33

E-mail : proctobouc@gmail.com

Text word count: 3296 words

Keywords: Crohn's disease; Anoperineal lesions;Anal fistulas; Abscess; Anal stenosis;

Guidelines;Rrecommendations. 


\section{ABSTRACT \\ Background}

Ano-perineal lesions (APL) occurrence is a significant event in the evolution of Crohn's disease (CD). Their management should involve a multidisciplinary approach combining the knowledge of the gastroenterologist, the colo-rectal surgeon and the radiologist who have appropriate experience in this area.Given the low level of evidence of medical and surgical available strategies, the aim of this work was to establish French expert consensus on management of anal Crohn's diease. These recommendations were led under the aegis of the Société Nationale Française de Colo-Proctologie. They report a consensus on the management of perianal Crohn's disease lesions, including fistulas, and also ulcerations and anorectal stenosis and propose an appropriate treatment strategy, as well as sphincter-preserving and multi-disciplinary management.

\section{Methodology}

A panel of French gastro-enterologists and colo-rectal surgeons with expertise in Inflammatory Bowel Diseases reviewed literature in order to provide practical management pathways for perianal $\mathrm{CD}$. Analysis of the literature was made according to the recommendations of the Haute Autorité de Santé (HAS) allowing to establish a level of proof for each publication, and then to propose a rank of recommendation. When lack of factual data precluded to establish a rank of recommendation according to the HAS, proposals based on expert opinion were written. Therefore when all the authors agreed on a consensual statement, it was then submitted to all the members of the SNFCP. As initial literature review 
stopped in December 2014, more recent European or international guidelines have been published during the interval, and therefore included for analysis.

\section{Results}

MRI is recommended for complex secondary lesions, particularly after failure of previous medical and/or surgical treatments. For severe anal ulcerations of Crohn's disease, maximal medical treatment with anti-TNF agent is recommended, because of their risk of destructive evolution. After prolonged drainage of simple anal fistula by a flexible elastic loop or looselytied seton, and after obtaining luminal and perineal remission by immunosuppressive therapy and/or anti-TNF agents, the surgical treatment options to be discussed are simple seton removal or injection of the fistula tract with biological glue. After prolonged loose-seton drainage of the complexe AFCD, and after obtaining luminal and perineal remission with anti-TNF \pm immunosuppressive therapy, surgical treatment options are simple removal of seton and rectal advancement flap. Colostomy is indicated as a last option for severe APL, possibly associated with a proctectomy if there is refractory rectal involvement after failure of other medical and surgical treatments. The evaluation of anorectal stenosis of Crohn's disease (ARSCD) requires a physical examination, sometimes under anesthesia, plus endoscopy with biopsies and MRI to describe the stenosis itself, to identify associated inflammatory, infectious or dysplastic lesions, and to search for injury or fibrosis of the sphincter. Therapeutic strategy for ARSCD requires medical-surgical cooperation. 


\section{Background}

Anoperineal lesions (APL) is a significant event in the evolution of Crohn's disease (CD). The management of these lesions is particularly difficult due to the tendency to tissue destruction and recurrence, and also to the serious impact on continence, sexuality and quality of life. The presence of APL when CD is diagnosed is a poor prognostic factor, especially in young adults $[1,2]$. In a third to a half of cases, APL reveals CD [3]. Among the different types of APL, abscess is the most frequent; the cumulative incidence of anoperineal fistula at 10 years is estimated to be between 21 and 33\% [3,4]. Given the low level of evidence for the medical and surgical treatment strategies available, we carried out the present review with the aim of establishing French expert consensus guidelines for the management of anal Crohn's diease. We established national recommendations based on literature analysis and on our experience, under the aegis of the Société Nationale Française de Colo-Proctologie (SNFCP) These recommendations represent a consensus regarding the management of perianal lesions in $\mathrm{CD}$, including fistulas, ulcers and anorectal stenosis and cover appropriate treatment strategy, as well as sphincter-preserving and multidisciplinary management.

\section{Materials and methods}

A panel of French gastroenterologists and colorectal surgeons with expertise in Inflammatory Bowel Diseases reviewed the literature in order to provide practical management pathways for perianal $\mathrm{CD}$. The authors reviewed all the aspects of perianal $\mathrm{CD}$, from diagnosis to treatment. Statements were associated with Grade of Recommendation, and two management 
algorithms were designed for anorectal ulcer and anorectal stricture in CD.

All the authors searched the Pubmed and Cochrane databases for articles published since 1970. An analysis of the literature was made according to the recommendations of the Haute Autorité de Santé (HAS) allowing us to establish a level of proof for each publication, and then to propose a rank of recommendation. When lack of factual data precluded establishing a rank of recommendation according to the HAS, proposals based on expert opinion were written. Therefore when all the authors agreed on a consensus statement, it was then submitted to all the members of the SNFCP. Graded from 1 to 9 were attributed according to the RAND/UCLA method, and analysis of the results and eventual rewriting of the statement was done by the coordinator of this work. These statements were named "professional agreement" or "AP". As the initial literature review stopped in December 2014 more recent European or international guidelines published since then have been included for analysis [57].

\section{1- Classification for APL in CD}

Multiple classifications of APL associated with CD have been proposed, each based on different features: pathogenesis, anatomy, symptoms, quality of life or prognosis. They make possible assessment of the initial severity of anoperineal involvement, and the response to treatment, and help to guide therapy. In clinical practice, most experts use the Cardiff UFS classification [8] to describe APL, or the American Gastroenterological Association classification [9] for the particular case of fistulas. The Perianal Disease Activity Index (PDAI) score is the most frequently used to assess the clinical severity of perianal involvement with CD [10]. New scores evaluating digestive performance or the handicaps due to the disease make possible a different assessment of CD. Their relevance in the global care of the disease is still under evaluation. 
The majority of the experts use the classification UFS of Cardiff to describe anorectalCD. PDAI is advocated to evaluate the clinical severity of anal CD.

\section{2- Imaging of APL in CD}

Imaging studies of APL complement data obtained from clinical evaluation, physical examination and rectal endoscopy. The role of imaging for primary lesions such as ulcers and fissures has not been evaluated to date. For patients with abscesses and strictures, most authors recommend performing an imaging study, particularly for patients who fail to respond to medical or surgical treatment and for patients suffering from anal incontinence $[11,12]$. This recommendation could be extended to all secondary lesions, even simple ones, because of the potential for progression, diagnostic difficulties, and severity of functional outcomes [13-15]. Imaging studies help to assess the anatomic extent of suppurating lesions (fistulous tracts and diverticula), the anatomy of the sphincter, and the appearance of the rectal wall. The preferred imaging study is perineal magnetic resonance imaging (MRI). MRI in combination with examination under anesthesia (EUA) should achieve a $100 \%$ level of accuracy $[3,16,17]$. Results of MRI may change the fistulae surgical approach in $10-20 \%$ of cases by identifying extensions of sinus tracts not identified on EUA [11,18-22]. MRI allows the surgeon to significantly reduce the recurrence rate after surgery and to predict its site in $52 \%$ of cases [22]. MRI can also differentiate between inflammatory and fibrotic fistulous tracts, and assess the degree of rectal involvement; findings concord well with endoscopic results [23-26]. The van Assche MRI score can help in the management of APL due to CD, but its reproducibility and prognostic value have not yet been assessed [26]. Endoanal ultrasonography (EAUS) may be an alternative imaging study. Its diagnostic accuracy for CD-related APL is estimated to be 56 - $100 \%$.Compared to MRI, EAUS offers poorer 
definition of secondary sinus tracts but better detection of the internal opening and better evaluation of the sphincter. It does not evaluate the inflammatory character of lesions [27-30].

\section{Key points on imaging of APL in CD:}

- imaging is recommended for complex secondary lesions, particularly after failure of previous medical and/or surgical treatments (grade B);

- imaging may also be recommended for simple secondary lesions, because of prognostic and therapeutic implications (grade B);

- for imaging of APL, first line examination should be MRI (grade B);

- addition of EUA may improve the accuracy of MRI (grade B);

- EAUS, possibly associated with injection of hydrogen peroxide, offers the advantage of 3-D assessment and may be equivalent to MRI (grade B);

- computed tomography and fistulogram have no place for this indication (grade B and C respectively);

- if MRI and EAUS are unavailable, examination under general anesthesia is required (grade C);

- the prognostic value of imaging (including MRI) in the therapeutic evaluation and its impact on the management of patients has yet to be defined (grade B).

\section{3- Therapeutic management of APL in CD}

There is no consensus today on the management of CD related APL, particularly in the case of ulcers or primary lesions. For suppurative lesions, data from the current literature indicate a strategy, based primarily on initial surgical drainage followed by medical treatment of the disease (grade B). Oral antibiotics (quinolones and metronidazole) have demonstrated a 
transitory efficacy while awaiting a response to tumor necrosis factor-alpha (TNF) blockers. Moreover, while the use of infliximab for this indication is based on large randomized controlled studies [31,32], the efficacy of other anti-TNF agents and conventional immunosuppressive agents (azathioprine, methotrexate, ciclosporine) is more difficult to interpret. Finally, the efficacy of other therapeutic agents (tacrolimus, thalidomide) has not been proven to date.

\section{3-a- Treatment of anal ulcers in CD}

Anal ulcers associated with CD (AUCD) are specific inflammatory lesions of CD. These primary lesions are classified according to the Cardiff UFS classification [8]. They can be painful when they are extensive or penetrating, resulting in abscesses or fistulas and ultimately, potentially in sphincter destruction or anal stenosis. However, the natural progression of these lesions is unknown. The cumulative probability of developing AUCD within 10 years of initial diagnosis of CD exceeds $25 \%$ [33]. AUCD are indicators of disease severity and the frequency of their occurrence increases with more distal colonic intestinal involvement $[34,35]$. Surgical treatments that could expose patients to poor healing, or increase the risk of suppuration or secondary incontinence should be avoided [insufficient evidence (IE)]. There is no specific controlled study on medical treatment of AUCD. Recommendations are therefore based on data from open studies, retrospective studies, or subgroup analyses, validated by professional consensus. For severe AUCD, maximal medical treatment with an anti-

TNF agent is recommended, because of the risk of destructive evolution (grade C). Infliximab is the medication of choice for AUCD for both induction and maintenance, preferably in combination with azathioprine [36-39] (grade C). The efficacy of adalimumab has not been specifically documented for AUC but, by extrapolation, it could be similar to that of 
infliximab [40,41] (IE). For a solitary superficial AUCD of limited extent without associated proctitis, close monitoring is recommended, sometimes associated with azathioprine therapy (IE). However, the efficacy of azathioprine alone has not been proved in the treatment of AUCD, even though it might reduce the incidence of these lesions (IE) [36-41]. Surgical drainage is only recommended in case of anorectal suppuration, abscess or complex fistula complicating a deep ulceration. If medical treatment for highly symptomatic and disabling AUCD fails, proximal gastrointestinal stomal diversion \pm proctectomy can be considered (IE). Because it entails a risk of anal incontinence, sphincterotomy should not be performed in the setting of proven anoperineal CD (IE).

A decision-making algorithm to guide treatment is proposed in Figure 1.

\section{3-b- Treatment of anoperineal fistula in (AFCD)}

\section{Overall framework of therapeutic management}

Perianal abscesses arise from either an infection of the pectineal glands of Hermann and Desfosses or from primary anorectal ulceration. They often develop complex and atypical fistulous tracts in CD. Most often, AFCD arise from AUCD and typically follow a chronic course of spontaneous relapse and recurrence [2-4,42]. The extent of intraluminal disease should always be assessed before initiating treatment, but treatment of AFCD is essential regardless of the specific treatment option (IE). The American Gastroenterological Association classification differentiates simple anal fistulas (inter- or low transsphincteric tract with a single external opening, without abscess, anorectal stenosis or inflammation) from all other complex fistulas [9]. The complexity of these fistulous tracts requires accurate preoperative mapping by imaging, principally by MRI and/or EAUS (grade C) $[9,13,14]$. The goal of treatment is to cure the suppuration while limiting anoperineal sequelae and, especially, preserving continence. Treatment includes a surgical phase of abscess drainage 
and a medical phase, specific to $\mathrm{CD}$, aimed at the underlying local and associated luminal inflammation. Drainage of abscesses and insertion of a seton through the fistulous tract are prerequisite for any management strategy, except in cases of dry and non productive fistula without abscess (grade B). A seton or elastic loop should be inserted and tied without tension, to avoid pain and sphincter transsection. Initial medical treatment may include the temporary use of ciprofloxacin for treatment of inflammatory AFCD during the first weeks of induction biotherapy (grade B). TNF-alpha antagonists are the most effective medical treatments for AFC at this time (grade A). Today, there is insufficient data to recommend the use of certolizumab or vedolizumab. There is lack of evidence to recommend the use of tacrolimus, thalidomide or cyclosporine. Too short a duration of seton drainage may favor recurrence of abscess while prolonged drainage may interfere with healing of the fistula [43]. Drainage for at least 3 weeks, seems to promote healing, particularly for complex fistulas, but should not exceed 34 weeks [44]. This drainage does not eliminate the risk of recurrence [45]. Local clinical or imaging criteria have no demonstrated a prognostic role for the timing of seton removal. After seton removal, MRI evidence of a persistent residual fistula despite closure of the cutaneous opening is a risk factor for recurrence [46].

\section{Simple AFCD}

Short-term treatment with ciprofloxacin can be recommended for the treatment of inflammatory symptomatic AFCD during the first weeks of induction biotherapy (grade B). For simple anal

fistula, azathioprine is justified by its moderate effectiveness for closing fistulas, and the reduced incidence of complex lesions requiring surgery (grade B). For simple AFCD, indications for infliximab and adalimumab therapy should be discussed based on the existence of perineal risk factors. Among surgical options, fistulotomy is contraindicated because of the 
risk of incontinence (IE), except for the rare cases of very superficial isolated fistulas in a patient with no perineal sequelae (IE). In patients with previously well drained fistulas, without associated abscesses and whose disease is medically controlled conservative surgical techniques can be discussed (biological glue and plug) [47,48], but only biological glue has demonstrated a significantly higher efficacy than simple seton removal [47] (grade A). The option of performing a rectal advancement flap should not be proposed for simple anal fistula because it is associated with a $10 \%$ risk of serious continence disorders [49]. Other surgical techniques such as ligation of the intersphincteric fistula tract (LIFT) and other reconstruction techniques have not proven their effectiveness.

\section{Key points in the treatment of simple AFCD:}

After prolonged drainage of simple anal fistula with a flexible elastic loop or loosely-tied seton, and after obtaining luminal and perineal remission with immunosuppressive therapy and/or anti-TNF agents, the surgical treatment options to be discussed are simple seton removal or injec-tion of the fistula tract with biological glue.

\section{Complex AFCD}

The management of complex AFCD is based on combined medical and surgical treatment (grade B). Ciprofloxacin can be recommended for early treatment of inflammatory symptomatic anal fistula during the first weeks of induction therapy with biologics (grade B). TNF antagonists are the most effective treatment for complex AFCD. Infliximab should be used, preferably in combination with immunosuppressive therapy (grade A). The efficacy of adalimumab for complex AFCD is based on non-dedicated clinical studies with lesser methodological reliability than studies of infliximab. However, the European Crohn's and Colitis Organisation (ECCO ) European consensus recommendations [50] put them on an equal footing. The efficacy of combination therapy with immunosuppressants is less clear for adalimumab than for infliximab [51]. The surgical option of fistulotomy is not recommended because of the risk of inducing incontinence (IE). In patients with previously well drained 
fistulas, without associated abscesses whose disease is medically controlled conservative surgical techniques such as biological glue and plug have not demonstrated a significantly better efficacy than simple seton removal (grade A) but these studies concern patients who were not receiving anti-TNF therapy $[47,48]$. The LIFT procedure should be evaluated as a possible alternative [52]. A low rectal advancement flap may be an option in very strictly selected patients with no evidence of proctitis or anal stenosis [53]. Flap is the surgical technique which has been most thoroughly evaluated to date in the management of anal fistulas in CD. Recently injection of stem cells into the tissues surrounding well drained and medically controlled fistulas has had promising results [54] (grade A) which need confirmation by other teams before recommendation. As a last option in severe AFCD, colostomy may be indicated, possibly combined with proctectomy if there is refractory rectal involvement after failure of other medical and surgical treatments, or if cancer is suspected.

\section{Key points in the treatment of complex anal fistula:}

After prolonged loose-seton drainage of complex AFCD, and after obtaining luminal and perineal remission with anti-TNF \pm immunosuppressive therapy (considered on a case-bycase basis), surgical treatment options are simple removal of seton and rectal advancement flap.

\section{Anorectovaginal fistula in CD (ARVFCD)}

Ciprofloxacin can be recommended for early treatment of inflammatory symptomatic anal fistula during the first weeks of induction therapy with biologics (grade B). TNF antagonists are the most effective treatment of complex anal fistulas, particularly in the case of ARVFCD and combined use with an immunosuppressive agent should be discussed on a case-by-case basis. The efficacy of infliximab is inferior and less sustained for ARVFCD than for other types of perianal fistulas [32]. Fistulotomy is contra-indicated due to secondary anatomic and functional muscle damage. Conservative techniques such as biological glue have not 
demonstrated a significantly superior efficacy to simple seton removal in patients not receiving anti-TNF therapy [47] (grade A). The technique of fistula resection and reconstruction has not been evaluated for ARVFCD, and is not recommended because of the risk of complications (IE). LIFT has not been evaluated for ARVFCD and cannot be recommended based on current data. As rectal or vaginal advancement flap results are variable, they cannot be routinely recommended. The technique of interposition of a vascularized gracilis muscle flap or the Martius procedure are indicated for ARVFCD after failure of conservative surgery [55-58] (grade C). There are no current data to favor one technique over the other. Proctectomy with intersphincteric amputation is indicated as a last option for severe ARVFCD with refractory rectal involvement after failure of other medical and surgical treatment [59]. While it results in improved quality of life, it is nevertheless associated with a $20 \%$ risk of persistent perineal sinus that may be difficult to manage [55] . The role of stomal diversion for ARVFCD has been widely discussed in the literature. While it enables a reduction in the activity of severe APC, the rate of restoration of digestive continuity remains low [60]. Considering the major tissue destruction and rearrangements of the Martius procedure or graciloplasty, it seems preferable to associate a proximal stomal diversion when performed, but the optimal site of this diversion was never been formally demonstrated.

\section{Key points in the treatment ofARVFCD:}

- after prolonged seton drainage of ARVFCD, and after obtaining luminal and perineal remission with anti- TNF \pm immunosuppressive therapy (considered case-by-case), surgical treatment options are simple seton removal and rectal or vaginal advancement flap (IE);

- in case of failure of one or two advancement flap procedures, a Martius flap interposition or a graciloplasty should be considered (grade C); 
- colostomy is indicated as a last option for severe ARVFCVD possibly associated with a proctectomy if there is refractory rectal involvement after failure of other medical and surgical treatments (IE).

\section{Ano-rectal stricture in CD(ARSCD)}

Fibrotic ARSCD usually occurs as a result of chronic inflammation and often occurs late in the course of the disease. The 1992 Cardiff classification [8] distinguishes Type 1 inflammatory stricture that relaxes under anesthesia and is amenable to medical treatment, from Type 2 fibrotic stricture which does not respond to medical treatment. The risk of colonic and anorectal dysplasia increases with the duration and severity of $\mathrm{CD}$; the possibility of local or associated upstream dysplasia must always be investigated. The evaluation of ARSCD requires a physical examination, sometimes under anesthesia, plus endoscopy with biopsies and MRI to describe the stenosis itself, to identify associated inflammatory, infectious or dysplastic lesions, and to search for injury or fibrosis of the sphincter. Therapeutic strategy for ARSCD requires medical-surgical cooperation. Treatment with dilation is simple and minimally invasive; if feasible, it is proposed as first line therapy for short symptomatic fibrotic strictures (grade C). Dilation can be proposed in cases of doubtful diagnosis in order to perform biopsies of the stenotic area or to perform an endoluminal examination (IE). There is a real risk of inducing incontinence by dilating the stricture in these patients with fibrotic lesions or of destroying the anal sphincter. Therefore, it is appropriate to assess the risk of anal incontinence before performing a dilation of anorectal stenosis (IE). If dilation of ARSCD is unsuccessful, conservative surgical alternatives should be studied before considering ano-proctectomy (IE). These techniques are only possible in the absence of luminal inflammatory damage and are, in fact, rarely performed. They have not been evaluated to date. Moreover, where dysplasia or cancer is identified, proctectomy should 
be proposed (IE) [61,62]. A proposed algorithm for management of anal stenosis is outlined in Figure 2.

The management of anorectal CD should involve a multidisciplinary approach combining the knowledge of the gastroenterologist, the colorectal surgeon and the radiologist who have appropriate experience in this area. Lack of data about spontaneous evolution of primary lesions, about prognostic factors in more complex lesions, and the wide range of available medical and surgical procedures explains why these recommendations have only been partially associated with an elevated rating grade. Future work should include assessment of patient preferences, quality of life and anal continence. This national consensus work should be repeated at a future date when more data and stronger prognostic indicators may be available.

\section{Conflict of interest:}




\section{References}

[1] Lapidus A, Bernell O, Hellers G, Lofberg R. Clinical course of colorectal Crohn's disease: a 35-year follow-up study of 507 patients. Gastroenterology 1998;114:1151—60.

[2] Beaugerie L, Seksik P, Nion-Larmurier I, Gendres JP, Cosnes J. Predictors of Crohn's disease. Gastroenterology 2006;130: 650—6.

[3] Schwartz DA, Loftus EV, Tremaine WJ, et al. The natural history of fistulizing Crohn's disease in Olmsted County, Minnesota. Gastroenterology 2002;122:875-80.

[4] Hellers G, Bergstrand O, Ewerth S, Holmstrom B. Occurrence and outcome after primary treatment of anal fistulae in Crohn's disease. Gut 1980;21:525-7.

[5] Gionchetti P, et al. 3rd European Evidence-based Consensus on the Diagnosis and Management of Crohn's Disease 2016: Part 2: Surgical Management and Special Situations. J Crohns Colitis 2017;11:135-149.

[6] Gecse KB, et al. A global consensus on the classification, diagnosis and multidisciplinary treatment of perianal fistulising Crohn's disease. Gut 2014;63:1381-92.

[7] Pellino G, et al. A think tank of the Italian society of colorectal surgery (SICCR) on the surgical treatment of inflammatory bowel disease using the Delphi method: Crohn's disease. Tech Coloproctol 2015;19:639-51.

[8] Hughes LE. Clinical classification of perianal Crohn's disease. Dis Colon Rectum $1992 ; 35: 928-32$.

[9] SandbornWJ, Fazio VW, Feagan BG, Hanauer SB, American Gas-troenterological Association Clinical Practice Committee. AGA technical review on perianal Crohn's disease. Gastroenterology 2003;125:1508-30.

[10] Irvine EJ. Usual therapy improves perianal Crohn's disease as measured by a new disease activity index. McMaster IBD Study Group. J Clin Gastroenterol 1995;20:27—32. 
[11] Beets-Tan RGH, Beets GL, van der Hoop AG, et al. Preoperative MR imaging of anal fistulas: does it really help the surgeon? Radiology 2001;218:75—84.

[12] Schratter-Sehn AU, Lochs H, HandI-Zeller L, Tscholakoff D, Schratter M.

Endosonographic features of the lower pelvic region in Crohn's disease. Am J Gastroenterol $1993 ; 88: 1054-7$.

[13] Pescatori M, Interisano A, Basso L. Management of perianal Crohn's disease. Dis Colon Rectum 1995;38:121-4.

[14] McKee RF, Keenan RA. Perianal Crohn's disease: is it all bad news? Dis Colon Rectum $1996 ; 39: 136-42$.

[15] American Gastroenterological Association Clinical Practice Committee. American Gastroenterological Association medical position statement: perianal Crohn's disease. Gastroenterology 2003;125:1503-7.

[16] Tang LY, Rawsthorne P, Bernstein CN. Are perineal and luminal fistulas associated in Crohn's disease? A population-based study. Clin Gastroenterol Hepatol 2006;4:1130—4. [17] Maccioni F, Colaiacomo MC, Stasolla A, Manganaro L, Izzo L, Marini M. Value of MRI performed with phased-array coil in the diagnosis and preoperative classification of perianal and anal fistulas. Radiol Med 2002;104:58 - 67.

[18] Lunniss PJ, Barker PG, Sultan AH, et al. Magnetic resonance imaging of fistula in ano. Dis Colon Rectum 1994;37: 708-18.

[19] de Souza NM, Hall AS, Puni R, Gilderdale DJ, Young IR, Kmiot WA. High resolution magnetic resonance imaging of the anal sphincter using a dedicated endo-anal coil. Comparison of magnetic resonance imaging with surgical findings. Dis Colon Rectum 1996;39:926-34. 
[20] Schwartz DA, Wiersema MJ, Dudiak KM, et al. A comparison of endoscopic ultrasound, magnetic resonance imaging, and examunder anesthesia for evaluation of Crohn's perianal fistulas. Gastroenterology 2001;121:1064-72.

[21] Chapple KS, Spencer JA, Windsor AC, et al. Prognostic value of magnetic resonance imaging in the management of fistula in ano. Dis Colon rectum 2000;43:511 -6.

[22] Buchanan GN, Halligan S, Bartram CI, Williams AB, Tarroni D. Clinical examination, endosonography, and MR imaging in preoperative assessment of fistula in ano: comparison with outcome-based reference standard. Radiology 2004;233:674-81.

[23] Cuenod CA, de Parades V, Siauve N, et al. MR imaging of ano-perineal suppurations. J Radiol 2003;84:516-28.

[24] Low RN, Sebrechts CP, Politoske DA, et al. Crohn disease with endoscopic correlation: single-shot fast spin-echo and gadolinium-enhanced fat-suppressed spoiled gradient-echo MR imaging. Radiology 2002;222:652-60.

[25] Florie J, Wasser MN, Arts-Cieslik K, Akkerman EM, Siersema PD, Stoker J. Dynamic contrast-enhanced MRI of the bowel wall for assessment of disease activity in Crohn's disease. AJR Am J Roentgenol 2006;186:1384—92.

[26] Van Assche G, Vanbeckevoort D, Bielen D, et al. Magnetic resonance imaging of the effects of infliximab on perianal fistulizing Crohn's disease. Am J Gastroenterol $2003 ; 98: 332-9$.

[27] Mallouhi A, Bonatti H, Peer S, Lugger P, Conrad F, Bodner G. Detection and characterization of perianal inflammatory disease: accuracy of transperineal combined gray scale and colour Doppler sonography. J Ultrasound Med 2004;23:19—27. [28] Zbar AP, Oyetunji RO, Gill R. Transperineal versus hydrogen peroxide-enhanced endoanal ultrasonography in never operated and recurrent cryptogenic fistula in ano: a pilot study. Tech Coloproctol 2006;10:297-302. 
[29] Domkundwar SV, Shinagare AB. Role of transcutaneous perianal ultrasonography in evaluation of fistulas in ano. J Ultrasound Med 2007;26:29—36.

[30] Maconi G, Ardizzone S, Greco S, Radice E, Bezzio C, Bianchi Porro G. Transperineal ultrasound in the detection of perianal and rectovaginal fistulae in Crohn's disease. Am J Gastroenterol 2007;102:2214-9.

[31] Present DH, Rutgeerts P, Targan S, et al. Infliximab for the treatment of fistulas in patients with Crohn's disease. N Engl J Med 1999;340:1398-405.

[32] Sands BE, Anderson FH, Bernstein CN, et al. Infliximab maintenance therapy for fistulizing Crohn's disease. N Engl J Med 2004;350:876—85.

[33] Peyrin-Biroulet L, Loftus Jr EV, Tremaine WJ, Harmsen WS, Zinsmeister AR, Sandborn WJ. Perianal Crohn's disease findings other than fistulas in a population-based cohort. Inflamm Bowel Dis 2012;18:43-8.

[34] Eglinton TW, Roberts R, Pearson J, et al. Clinical and genetic risk factors for perianal Crohn's disease in a population-based cohort. Am J Gastroenterol 2012;107:589—96. [35] Siproudhis L, Mortaji A, Mary JY, Juguet F, Bretagne JF, Gosselin M. Anal lesions: any significant prognosis in Crohn's disease? Eur J Gastroenterol Hepatol 1997;9:239—43. [36] Cosnes J, Bourrier A, Laharie D, et al. Early administration of azathioprine vs. conventional management of Crohn's Disease: a randomized controlled trial. Gastroenterology 2013;145:758—65.

[37] Ouraghi A, Nieuviarts S, Mougenel JL, et al. Infliximab therapy for Crohn's disease anoperineal lesions. Gastroenterol Clin Biol 2001;25:949—56.

[38] Bouguen G, Trouilloud I, Siproudhis L, et al. Long-termoutcome of non-fistulizing (ulcers, stricture) perianal Crohn's disease in patients treated with infliximab. Aliment Pharmacol Ther 2009;30:749—56. 
[39] Colombel JF, Sandborn WJ, Reinisch W, et al. Infliximab, azathioprine, or combination therapy for Crohn's disease. N Engl J Med 2010;362:1383—95.

[40] Colombel J-F, Schwartz DA, Sandborn WJ, et al. Adalimumab for the treatment of fistulas in patients with Crohn's disease. Gut 2009;58:940—8.

[41] Dewint P, Hansen BE, Verhey E, et al. Adalimumab combined with ciprofloxacin is superior to adalimumab monotherapy in perianal fistula closure in Crohn's disease: a randomised, double-blind, placebo controlled trial (ADAFI). Gut 2014;63:292—9.

[42] Bell SJ, Williams AB, Wiesel P, Wilkinson K, Cohen RC, Kamm MA. The clinical course of fistulating Crohn's disease. Aliment Pharmacol Ther 2003;17:1145—51.

[43] Tanaka S, Matsuo K, Sasaki T, Nakano M, Sakai K, Beppu R, et al. Clinical advantages of combined seton placement and infliximab maintenance therapy for perianal fistulizing Crohn's disease: when and how were the seton drains removed? Hepatogastroenterology $2010 ; 57: 3-7$.

[44] Bouguen G, Siproudhis L, Gizard E, et al. Long-term outcome of perianal fistulizing Crohn's disease treated with infliximab. Clin Gastroenterol Hepatol 2013;11:975—81. [45] Buchanan GN, Owen HA, Torkington J, Lunniss PJ, Nicholls RJ, Cohen CR. Long-term outcome following loose-seton technique for external sphincter preservation in complex anal fistula. Br J Surg 2004;91:476—80.

[46] Haggett PJ, Moore NR, Shearman JD, Travis SP, Jewell DP, Mortensen NJ. Pelvic and perineal complications of crohn's disease: assessment using magnetic resonance imaging. Gut 1995;36:407-10.

[47] Grimaud JC, Munoz-Bongrand N, Siproudhis L, et al. Fibrin glue is effective healing perianal fistulas in patients with Crohn's disease. Gastroenterology 2010;138:2275—81. [48] Senéjoux A, Siproudhis L, Abramowitz L, et al. Fistula Plug in Fistulising Ano-Perineal Crohn's Disease: a Randomised Controlled Trial. J Crohns Colitis. 2016 Feb;10(2):141-8. 
[49] Soltani A, Kaiser AM. Endorectal flap for cryptoglandular or Crohn's fistula in ano. Dis Colon Rectum 2010;53:486-95.

[50] Van Assche G, Dignass A, ReinischW, et al. The second European evidence-based consensus on the diagnosis and management of Crohn's disease: special situations. ECCO. J Crohn's Colitis 2010;4:63-101.

[51] Reenaers C, Louis E, Belaiche J, et al. Does co-treatment with immunosuppressors improve outcome in patients with Crohn's disease treated with adalimumab? Aliment Pharmacol Ther 2012;36:1040-8.

[52] Gingold DS, Murrell ZA, Fleshner PR. A prospective evaluation of the ligation of the intersphincteric tract procedure for complex anal fistula in patients with Crohn disease. Ann Surg 2014;260:1057-61.

[53] Ruffolo C, Scarpa M, Bassi N, Angriman I. A systematic review on advancement flaps for rectovaginal fistula in Crohn's disease: transrectal vs. transvaginal approach. Colorectal Dis 2010;12:1183-91.

[54] Panés J, García-Olmo D, Van Assche G, et al. Expanded allogeneic adipose-derived mesenchymal stem cells (Cx601) for complex perianal fistulas in Crohn's disease: a phase 3 randomised, double-blind controlled trial. Lancet 2016;388:1281-90.

[55] Lefevre JH, Bretagnol F, Maggiori L, Alves A, Ferron M, Panis Y. Operative results and quality of life after gracilis muscle transposition for recurrent rectovaginal fistula. Dis Colon Rectum 2009;52:1290-5.

[56] Furst A, Schmidbauer C, Swol-Ben J, Iesalnieks I, Schwandner O, Agha A. Gracilis transposition for repair of recurrent anovaginal and rectovaginal fistulas in Crohn's disease. Int J Colorectal Dis 2008;23:349-53.

[57] Pitel S, Lefevre JH, Parc Y, Chafai N, Shields C, Tiret E. Martius advancement flap for low rectovaginal fistula: short- and long-term results. Colorectal Dis 2011;13:e112—5. 
[58] Songne K, Scotte M, Lubrano J, Huet E, Lefebure B, Surlemont Y, et al. Treatment of anovaginal or rectovaginal fistulas with modified Martius graft. Colorectal Dis 2007;9:653. [59] Regimbeau JM, Panis Y, Marteau P, Benoist S, Valleur P. Surgical treatment of anoperineal Crohn's disease: can abdominoperineal resection be predicted? J Am Coll Surg 1999;189: $171-6$.

[60] Regimbeau JM, Panis Y, Cazaban L, et al. Long-term results of faecal diversion for refractory perianal Crohn's disease. Colorectal Dis 2001;3:232-7.

[61] Annese V, et al. European Evidence-based Consensus: Inflammatory Bowel Disease and Malignancies. J Crohns Colitis 2015;9:945-65.

[62] Rieder F, et al. European Crohn's and Colitis Organisation Topical Review on Prediction, Diagnosis and Management of Fibrostenosing Crohn's Disease. J Crohns Colitis 2016;10:87385. 
Figure 1. Management algorithm for anal ulcerations in Crohn's disease (AUCD)

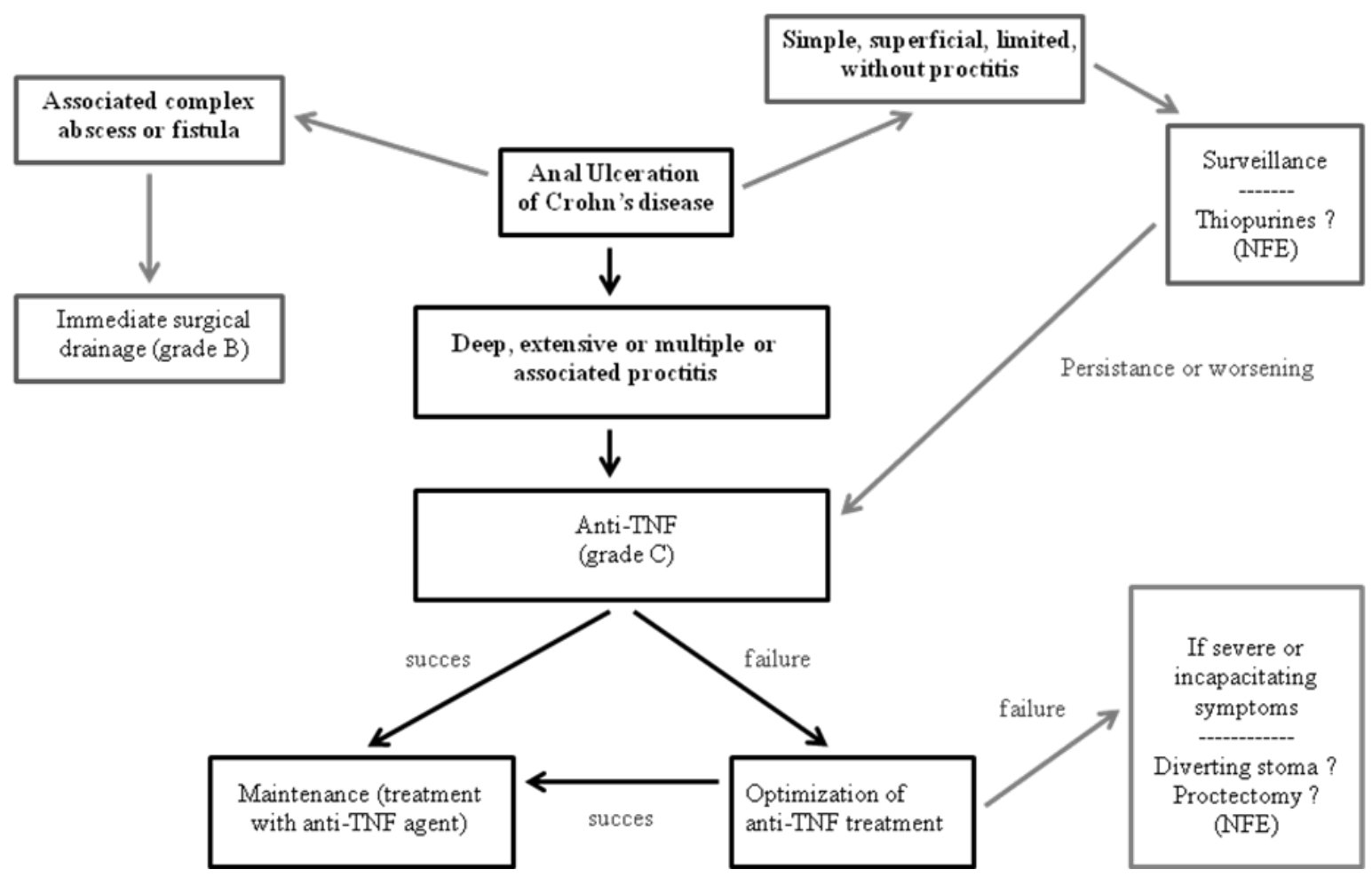


Figure 2. Management algorithm for anorectal stenosis in Crohn's disease

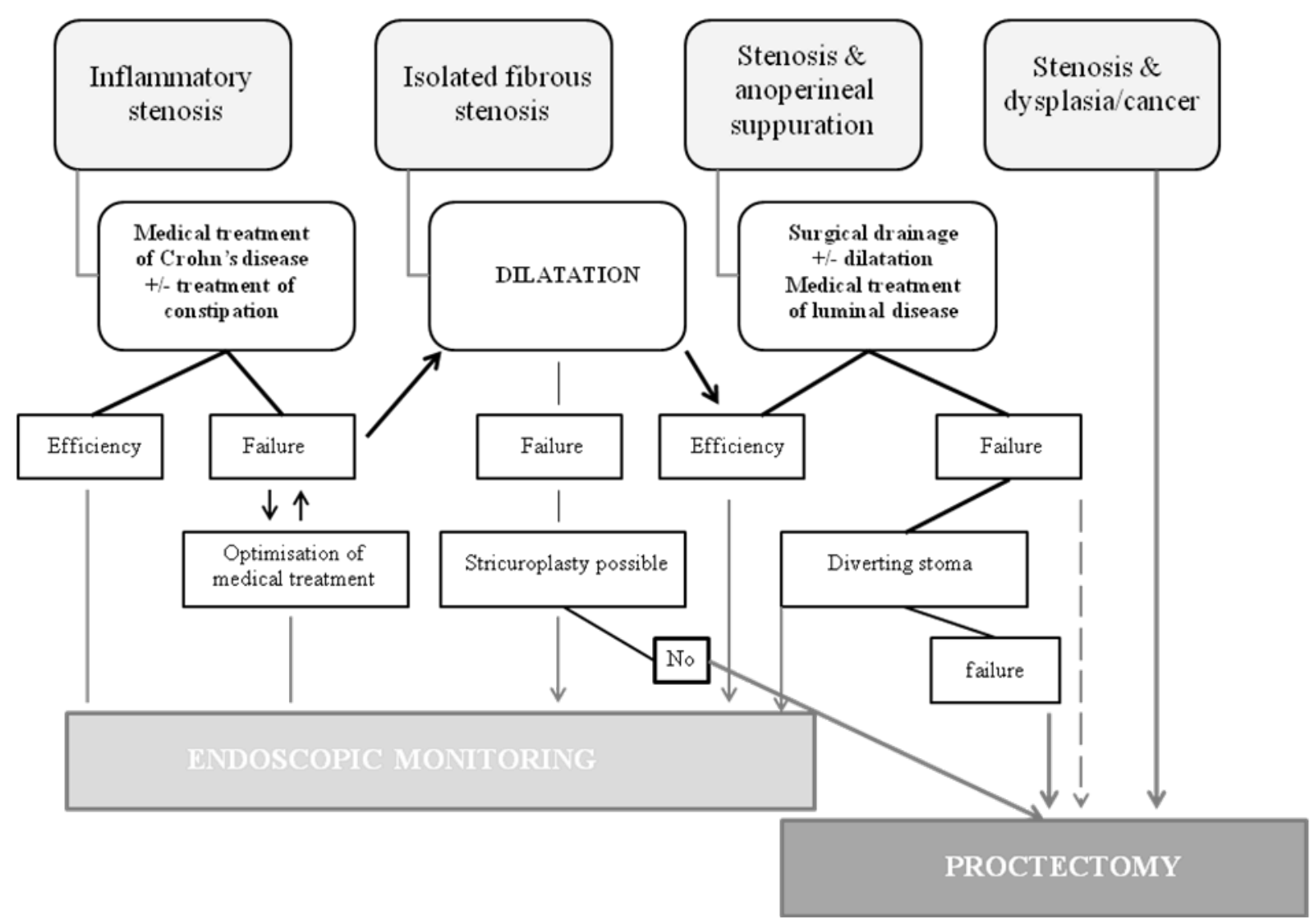

